\title{
$\mathrm{J} 13117$
}

\section{ナノワイヤにより凹凸を形成した $\mathrm{SiC}$ 薄膜の摩擦係数評価}

\section{Evaluation of Friction Coefficient of SiC Film with Projections Formed by Nano-wires}

\author{
○正 加藤 昌彦*1, 小林 健吾*2 \\ Masahiko KATO ${ }^{* 1}$ and Kengo KOBAYASHI ${ }^{* 2}$, \\ ${ }^{* 1}$ 福山大学 Fukuyama University \\ *2 福山大学 学 Bachelor Student, Fukuyama University
}

Key Words : SiC Film, Friction Coefficient, Nano-wires, Plasma discharging,

\section{○緒言}

著者らが発見したナノワイヤを基材表面に形成させたのち薄膜を製膜すると,表面に微細な凹凸を形成可能で ある(1)。これまでの研究で, 摩擦係数はナノワイヤ長さに影響を受けろこノを確認りてていろ. 本研究ではナノワ イヤ長さが短い場合, 摩擦係数におよぼす影響を調べた.

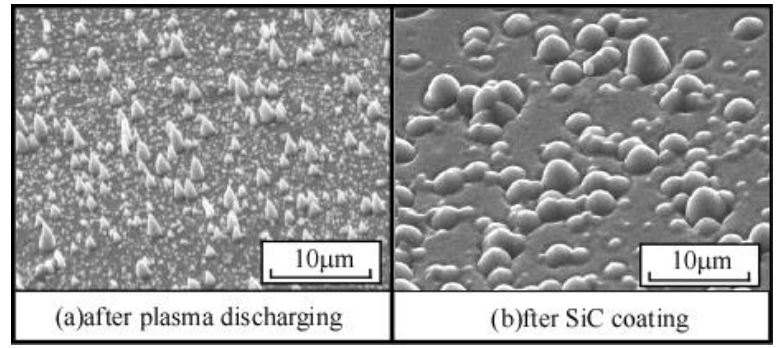

Fig.1 Surface after plasma discharging(a) and $\mathrm{SiC}$ coating(b).

\section{実験方法}

高速度鋼（JIS:SKH55）基板表面に種々の条件でプラズマ放 電し，ナノワイヤを形成させた．形成例を図 1(a)に示す. 直径 数 $\mu \mathrm{m}$ 長さ $10 \mu \mathrm{m}$ 程度のナノワイヤが多数形成される.これ の表面に $\mathrm{SiC}$ 薄膜を図 1 (b)に示寸ようにスパッタコーティング した. $\mathrm{SiC}$ 表面に平均高さ $h_{a v e}=1.67 \mu \mathrm{m}$ の突起が形成されてい る. 摩擦試験は図 2 に示寸装置を用い，荷重 $0.98 \mathrm{~N} ， 0.05 \mathrm{~m} / \mathrm{s}$ の すべり速度で試験した。

\section{実験結果及び考察}

無突起及び凹凸高さが $0.12 \mu \mathrm{m}$ および $1.17 \mu \mathrm{m}$ の試験片で得 られた摩擦係数とディスク回転数 $N$ の関係を図 3 に示寸. 摩擦 係数は凹凸の高さによりかわり，凹凸高さが $0.12 \mu \mathrm{m}$ では無突 起試験片と同等であり, 凹凸高さが $1.17 \mu \mathrm{m}$ では, 低下するこ とがわかる。

○結言

ナノワイヤ微細凹凸高さにより摩擦係数は変化する. 本研究は JSPS 科研費 JP17K06054 の助成を受けて行った.

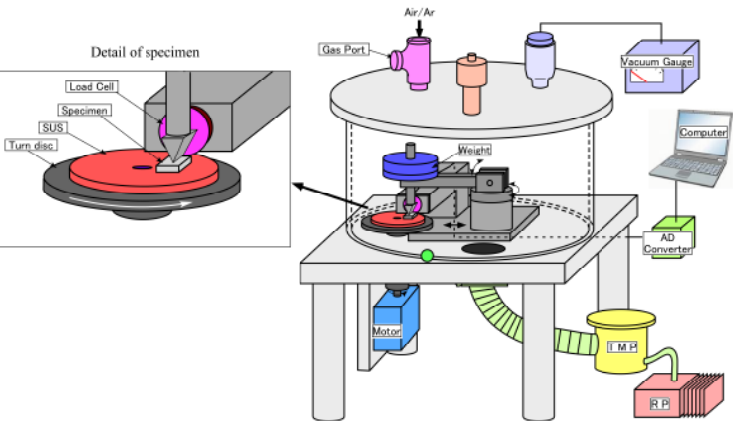

Fig.2 Friction testing machine.

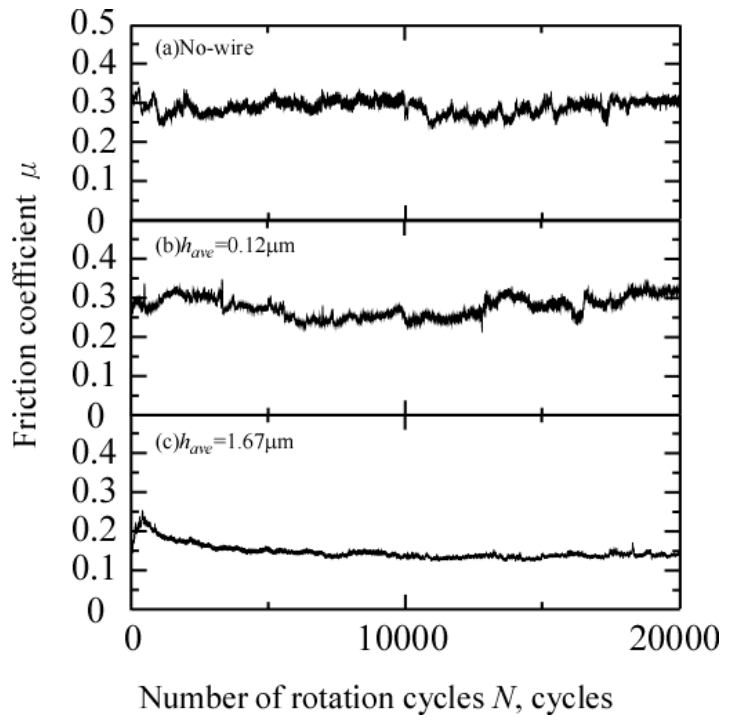

Fig.3 Relationship between number of rotation cycles and friction coefficient.

\section{文献}

(1) 加藤昌彦, 林真人, 曙紘之, 菅田淳, “プラズマ放電による合金鋼表面へのナノ・マイクロロッド状炭化物の形成”, 日本金属学会誌，Vol. 75, No. 12 (2011), pp. 705-707. 